Tersedia online di: http://ejournal-balitbang.kkp.go.id/index.php/JP
e-mail:jurnalpari@gmail.com
JURNAL PARI
Volume 4 Nomor 1 Juli 2018
p-ISSN: 2502-0730
e-ISSN : 2549-0133

\title{
KINERJA ASUPAN PADA LAPORAN TAHUNAN : STUDI KASUS LAPORAN TAHUN 2016 PADA PERPUSTAKAAN BALAI BESAR RISET SOSIAL EKONOMI KELAUTAN DAN PERIKANAN
}

\author{
SITI NURHAYATI \\ Balai Besar Riset Sosial Ekonomi Kelautan dan Perikanan \\ Diterima tanggal : 6 Februari 2018 Diterima setelah perbaikan : 16 Mei 2018 \\ disetujui terbit : 22 Juni 2018
}

\begin{abstract}
ABSTRAK
Laporan tahunan di perpustakaan dibuat sebagai upaya untuk mengetahui pencapaian terhadap visi, misi dan tujuan perpustakaan serta alat pertanggungjawaban pelaksanaan dan penyelenggaraannya. Ada tiga kinerja yang dijadikan dasar pada laporan tahunan Perpustakaan Balai Besar Riset Sosial Ekonomi Kelautan dan Perikanan 2016, salah satunya adalah kinerja asupan. Metode penelitian yang digunakan adalah kualitatif non interaktif yang di padukan dengan studi literatur sekunder yang dianalisis secara deskritif. Dengan total populasi sejumlah 89 hasil yang di capai dari kinerja asupan ini dijawab dengan di ketahuinya jumlah pengguna potensial sebesar 89 orang, total koleksi yang di miliki sejumlah 1.818 eksemplar. Penambahan koleksi secara pembelian yang tidak ada pada tahun 2016 tetap menjadikan besaran persentase buku berdasarkan jenis buku teks sebesar $71 \%$. Rasio pengguna sebanyak 10.5 , namun kemutakhiran koleksi hanya sebesar $17 \%$. Jumlah jam pelayanan selama 40 jam per pekan. Dukungan sarana katalog daring hanya 1 buah komputer. Rasio pustakawan terhadap staf perpustakaan adalah 2:1 dengan library registration sebesar $100 \%$.
\end{abstract}

\section{Kata Kunci : Pengukuran Kinerja, Kinerja perpustakaan, Laporan tahunan}

\begin{abstract}
The annual report of Research Institute of Marine and Fisheries for Socio-Economic Development (RMFFSED) Library is made to find out its achievement in vision, mission and objectives as well as a tool of accountability of its implementation. There are three basic aspects of the report in 2016, one of which is the performance of data processing. The method used in this research is the qualitative non-interactive combined with the descriptively analyzed secondary literature study. Of the total library member population of 89 people, the results achieved from the processed data is that the number of potential users are 89 people, and the total collections are 1,818 copies since there is no collection addition in 2016, the percentage of text books remains $71 \%$. The user rate is 10.5 however, the collection update is only $17 \%$, and the number of hours of service is 40 hours per week. Online catalog facility is only one computer. The ratio of librarian to library staff is 2:1 with library registration of $100 \%$
\end{abstract}

Keyword : Performance Measurement, Library Performance, Annual Report. 


\section{PENDAHULUAN}

Laporan tahunan perpustakaan (Library Annual Report) adalah dokumen komunikasi formal yang meliputi informasi kuantitatif, naratif, foto, dan grafik. Dengan laporan tahunan, perpustakaan Balai Besar Riset Sosial Ekonomi Kelautan dan Perikanan (BBRSEKP) mengkomunikasikan hasil operasinya kepada lembaga induk, dalam hal ini BBRSEKP. Jadi jika dilihat dari perspektif teori agensi, laporan tahunan dapat dianggap sebagai alat pertanggungjawaban manajemen perpustakaan sebagai agen kepada BBRSEKP sebagai stakeholder secara umum. Kepentingan utama pemakai laporan tahunan apakah informasi yang diberikan dapat digunakan dalam pengambilan keputusan baik terkait kebijakan maupun keuangan sesuai dengan kepentingan masing-masing stakeholder.

Ketika perpustakaan BBRSEKP di tanya prestasi apa yang telah di capai selama satu tahun terakhir, maka jawaban yang diberikan bisa sangat bervariasi, oleh karena itu sejak tahun 2012, penulis menggunakan pengukuran kinerja yang di keluarkan oleh Forum Perpustakaan Perguruan Tinggi, karena hingga saat ini, belum ada pedoman pengukuran kinerja untuk perpustakaan khusus, kecuali perpustakaan tertentu yang menggunakan standar dari ISO, yaitu standar ISO 11620:2008 Library and Documentation- Library Performance Indicator (ISO,2008), atau standar yang terbaru ISO 11620:2014 Information and Documentation-Library Performance Indicators.

Ada tiga jenis data yang harus selalu penulis laporkan pada waktu itu yaitu (1) jumlah pengunjung perpustakaan selama satu tahun, (2) jumlah peminjam buku perpustakaan selama satu tahun, dan (3) jumlah buku yang dipinjam selama satu tahun. Pertanyaannya adalah, apakah hanya tiga data tersebut yang dapat menunjukkan prestasi sebuah perpustakaan? Apakah benar kesibukan pustakawan bekerja di sebuah perpustakaan hanya dicerminkan oleh ketiga hal tersebut? Jika ya, apakah prestasi kerja yang dicerminkan dengan tiga hal tersebut dapat diperbandingkan dengan perpustakaan lain? Pertanyaan-pertanyaan inilah yang perlu dijawab dengan pengukuran kinerja yang seragam di seluruh perpustakaan. Dengan pengukuran kinerja yang seragam tersebut maka prestasi kerja perpustakaan dapat saling diperbandingkan antar perpustakaan. Begitu juga sebuah perpustakaan dapat mengetahui perkembangan prestasinya dengan cara membandingkan prestasi kerja tahun sekarang dengan prestasi kerja tahun-tahun sebelumnya.

\section{TINJAUAN PUSTAKA}

Jika mengutip karakteristik kualitatif informasi akuntansi dalam Statement of Financial Accounting Standars (SFAS) No. 2, maka sebuah laporan tahunan harus menyajikan informasi yang memenuhi kriteria sebagai berikut :

a) Kualitas yang berkaitan dengan pemakai spesifik, yaitu understandability. Kualitas mampu dipahami menyatakan bahwa informasi tidak dapat bermanfaat bagi pemakai yang tidak memahami informasi tersebut. Jadi pemakai laporan tahunan adalah pemustaka yang 'library science literate' bukan pemustaka yang naïf, yang hanya melihat pada sisi bottom line laporan jumlah kunjungan (ketermanfaatan.)

b) Kualitas primer yaitu relevan dan dapat diandalkan, informasi yang relevan artinya memiliki kapabilitas untuk membuat perbedaan dalam suatu keputusan dengan membantu pemakai informasi untuk membentuk prediksi tentang hasil dari kejadian masa lalu, sekarang, dan yang akan datang (nilai prediksi), atau dengan mengkonfirmasi harapan sebelumnya (nilai umpan balik).

c) Kualitas sekunder yaitu kompatibilitas dan konsistensi. Informasi mengenai suatu perpustakaan dapat bermanfaat jika dapat dibandingkan dengan informasi serupa pada perpustakaan lain (kompatibilitas) dan dapat dibandingkan dengan informasi serupa pada perpustakaan tersebut untuk beberapa periode atau titik waktu yang lain (konsistensi).

Meskipun laporan tahunan telah memenuhi kualitas tersebut di atas, informasi tersebut akan lebih bermanfaat bagi pemustaka eksternal apabila laporan tahunan tersebut sudah diaudit oleh auditor independen (bisa dari tim Perpustakaan NasionalPNRI), karena dapat meyakinkan pemustaka bahwa laporan tahunan dinyatakan sesuai dengan kriteria yang telah ditentukan. Selain itu, relevan juga berkaitan dengan ketepatan waktu. Dapat diandalkan artinya dapat menunjukkan kejujuran dalam penyajian. Agar dapat diandalkan maka harus memiliki tiga kualitas yaitu diversifikasi, penyajian secara jujur, dan netralitas.

Menurut Courtis (1995) laporan tahunan yang dikeluarkan perusahaan (dalam hal ini perpustakaan) merupakan data yang kredibel karena mengikuti aturan khusus, mencerminkan integritas manajemen dalam mengkomunikasikan secara obyektif dan komprehensif, dan yang utama telah melalui proses audit. Tanpa mempertimbangkan gaya penyajian, isi, pengorganisasian, grafik warna, pilihan gambar dan 
panjang laporan keseluruhan, serta intelegensi yang harus dikomunikasikan melalui dokumen tersebut, laporan tahunan harus dapat dijadikan sarana untuk melakukan (mengkonfirmasi) penilaian risk-return perpustakaan. Oleh karena itu komunikasi laporan tahunan harus efektif. Komunikasi yang efektif terjadi ketika pesan yang diterima oleh pembaca laporan tahunan diinterpretasikan sama seperti yang dimaksudkan oleh penyaji laporan tahunan berjalan dengan baik (Courtis, 1995). Kesulitan yang dihadapi berkaitan dengan pengkomunikasian laporan tahunan adalah pengungkapan naratif dalam laporan tahunan seringkali ditulis dalam tingkat komprehensi melebihi kapasitas pembacanya, sehingga laporan tahunan tradisional terlihat sangat kompleks dan menyebabkan information overload (Courtis, 1995). Penulisan yang secara sengaja maupun tidak sengaja sulit dipahami dalam rangka menutupi beberapa aspek perilaku korporat yang tidak baik akan menghasilkan konsekuensi yang sama. Berkaitan dengan hal tersebut, tulisan ini berusaha mengupas masalah kemampuan dibaca (readability) dan pemahaman (understanding) pemakai laporan tahunan sebagai salah satu alternatif untuk meningkatkan komunikasi antara perpustakaan dengan pihak-pihak yang berkepentingan, dalam hal ini lembaga induknya.

Tujuan dari penyusunan laporan tahunan adalah untuk menguraikan hal-hal yang diakui dan memberikan pengukuran yang relevan atas hal-hal tersebut di luar pengukuran yang digunakan dalam laporan keuangan. Selain itu laporan tahunan juga dapat menguraikan hal-hal yang diakui dan untuk memberikan pengukuran yang bermanfaat. Hal ini berdampak pula pada saat pengambil kebijakan dalam menetukan kebijakan-kebijakan terkait perpustakaan. Hal lain yang didapatkan adalah informasi penting yang memungkinkan para pengguna laporan tahunan untuk melakukan perbandingan dalam satu tahun dan diantara beberapa tahun, selain itu dapat membantu stakeholder untuk menilai tingkat urgensi perpustakaan tersebut.

Fungsi mendasar dari sebuah laporan tahunan yang dibuat oleh masing-masing perpustakaan, yaitu sumber dokumentasi informasi perpustakaan tentang apa yang telah dicapai perpustakaan selama setahun, sebagai alat pemasaran yang kreatif bagi perpustakaan melalui integritas desain dan tulisan. Menambah daya tarik perpustakaan di mata pemangku kebijakan dan pemustaka lain, sebagai dokumen lengkap yang menceritakan secara mendetail kinerja perpustakaan, beserta dengan ukuran kinerja perpustakaan dalam setahun, serta memberikan gambaran mengenai tugas, peran, dan pekerjaan masing-masing bidang.

\section{METODE PENELITIAN}

Penulisan makalah ini dilakukan dengan metode kualitatif non interaktif yang di padukan dengan studi literatur sekunder yang dianalisis secara deskritif. Metode penelitian kualitatif adalah metode penelitian yang digunakan untuk meneliti kondisi objek yang alamiah dimana penulis merupakan instrumen kunci. Pengambilan sampel untuk penelitian yang menggunakan metode kualitatif dilakukan secara purposive dan snowball. Teknik pengumpulan data dilakukan secara triangulasi kemudian dianalisis secara induktif. (Sugiono, 2013).

\section{HASIL DAN PEMBAHASAN}

Kinerja Asupan yang terdiri dari jumlah pengguna potensial, total koleksi yang di miliki, persentase jenis koleksi, jumlah koleksi dan rasio pengguna, kemutakhiran koleksi, pengadaan koleksi, jumlah jam pelayanan, katalog daring, rasio pustakawan dan registrasi perpustakaan adalah sub bagian dari tiga faktor kinerja yang dibuat dalam penyusunan laporan tahunan di Perpustakaan BBRSEKP. Pada makalah ini, penulis memaparkan data dari laporan tahunan Perpustakaan 2016. (annual report tahun 2016 di perpustakaan BBRSEKP.) Setelah adanya perubahan lokasi dari semula di wilayah Jakarta Pusat, kewilayah Ancol di Jakarta Utara. Hal ini memperngaruhi beberapa hal, diantaranya jumlah total koleksi dan jumlah pemustaka yang harus di layani oleh Perpustakaan BBRSEKP.

\section{KINERJAASUPAN}

Kumpulan data yang dihimpun dan diolah menjadi informasi berupa:

\section{JURISDICTION POPULATION}

Jumlah sivitas akademika Balai Besar Riset Sosial Ekonomi Kelautan dan Perikanan (BBRSE-KP) atau istilah yang digunakan dalam laporan ini adalah Jurisdiction Population adalah jumlah pengguna potensial dalam lingkungan Balai yang wajib dilayani oleh perpustakaan BBRSE-KP sampai dengan desember tahun berjalan. Laporan yang disajikan berupa tabel yang dibagi menjadi dua bentuk, berdasarkan status dan jabatan.

Dan untuk lebih memperkuat isi laporan, maka di tambahkan pula grafik dari pemustaka di perpustakaan BBRSEKP 
J.Pari Vol. 4 No. 1 Juli $2018: 1-9$

Tabel 1. Pengguna Potensial

No.

Status Kepegawaian

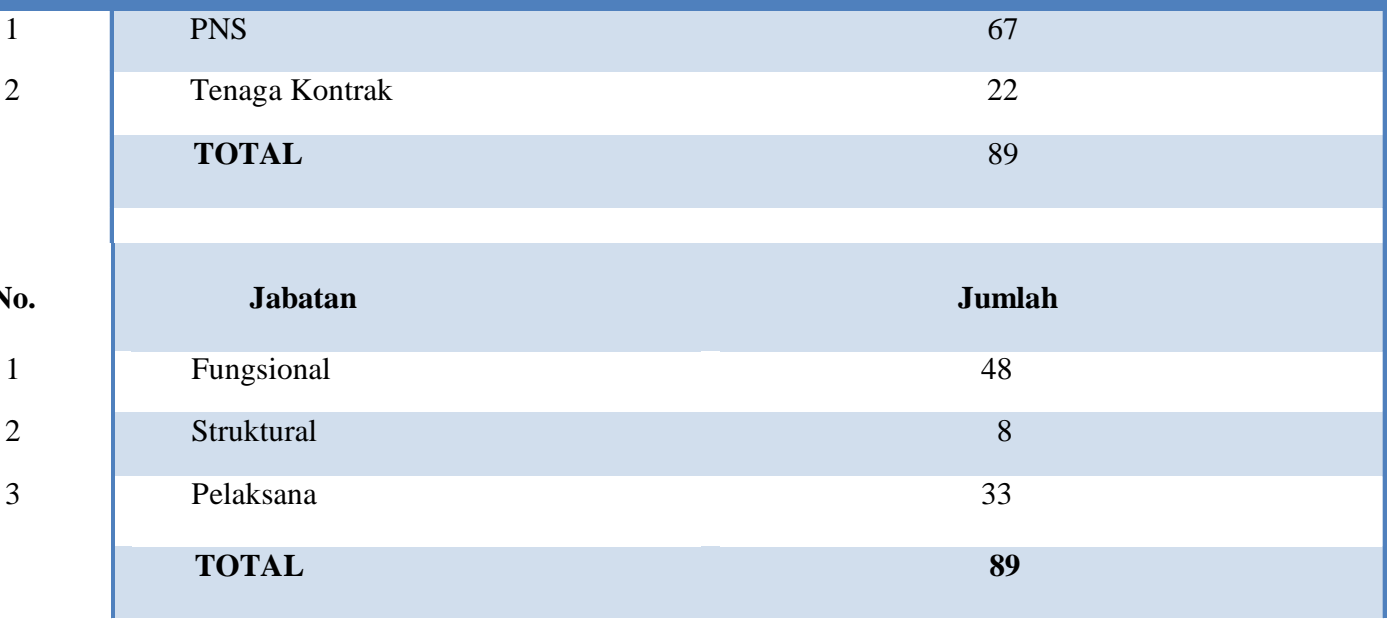

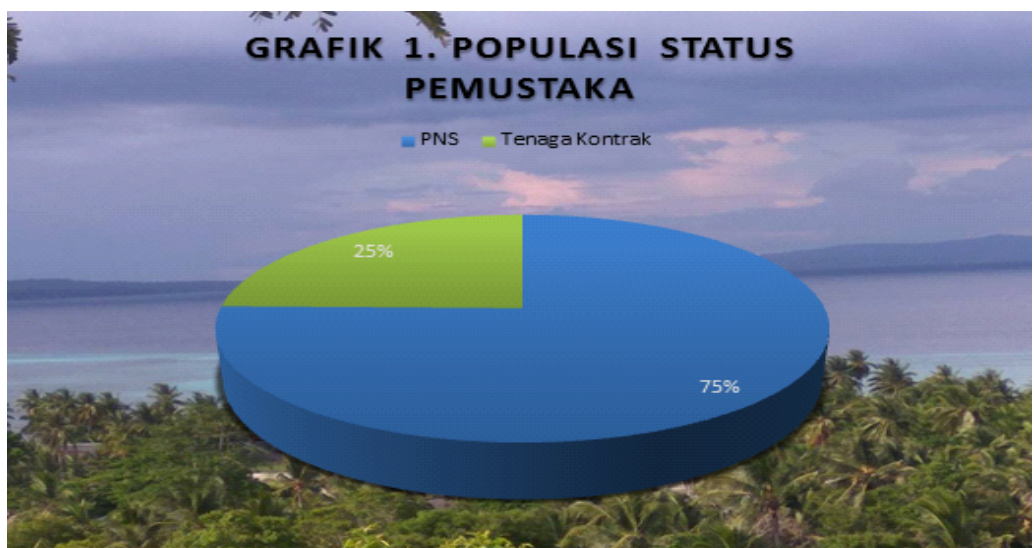

Gambar 1. Populasi Pemustaka di Perpustakaan BBRSEKP tahun 2016 berdasarkan Status Kepegawaian.

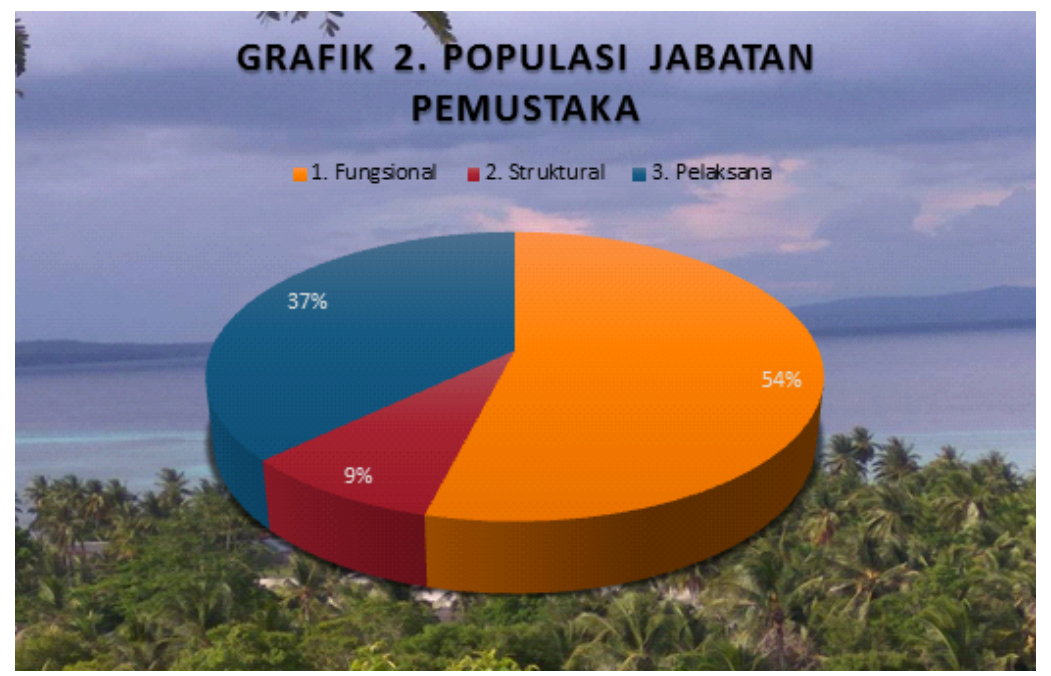

Gambar 2. Populasi pemustaka di Perpustakaan BBRSEKP tahun 2016 berdasarkan Jabatan 


\section{TOTAL COLLECTION (TC) HOLDINGS}

Total seluruh koleksi dalam eksemplar (Holdings) yang terdaftar di Sistem Automasi di Perpustakaan BBRSEKP yaitu SLIMs, (Senayan Library Management System) sampai dengan Desember 2016 sejumlah 936, dengan rincian yang dibuat pula dalam bentuk tabel dan grafik. Ada perubahan total koleksi perpustakaan BBRSEKP karena kegiatan weeding yang dilakukan bersamaan dengan mutasi ke Wilayah Ancol, selain itu pada tahun 2016 Perpustakaan BBRSEKP tidak melakukan pengadaan buku, sehingga pertambahn koleksi dari tahun 2015 tidak berubah banyak.

Tabel 2. Total Koleksi yang di miliki oleh Perpustakaan BBRSEKP tahun 2016

No.

Jenis Koleksi

Jumlah

\begin{tabular}{|l|ll|}
\hline 1 & Buku Teks & 664 \\
2 & Laporan / Prosiding & 119 \\
3 & Jurnal & 113 \\
4 & Buletin & 40 \\
& & $\mathbf{9 3 6}$ \\
\hline
\end{tabular}

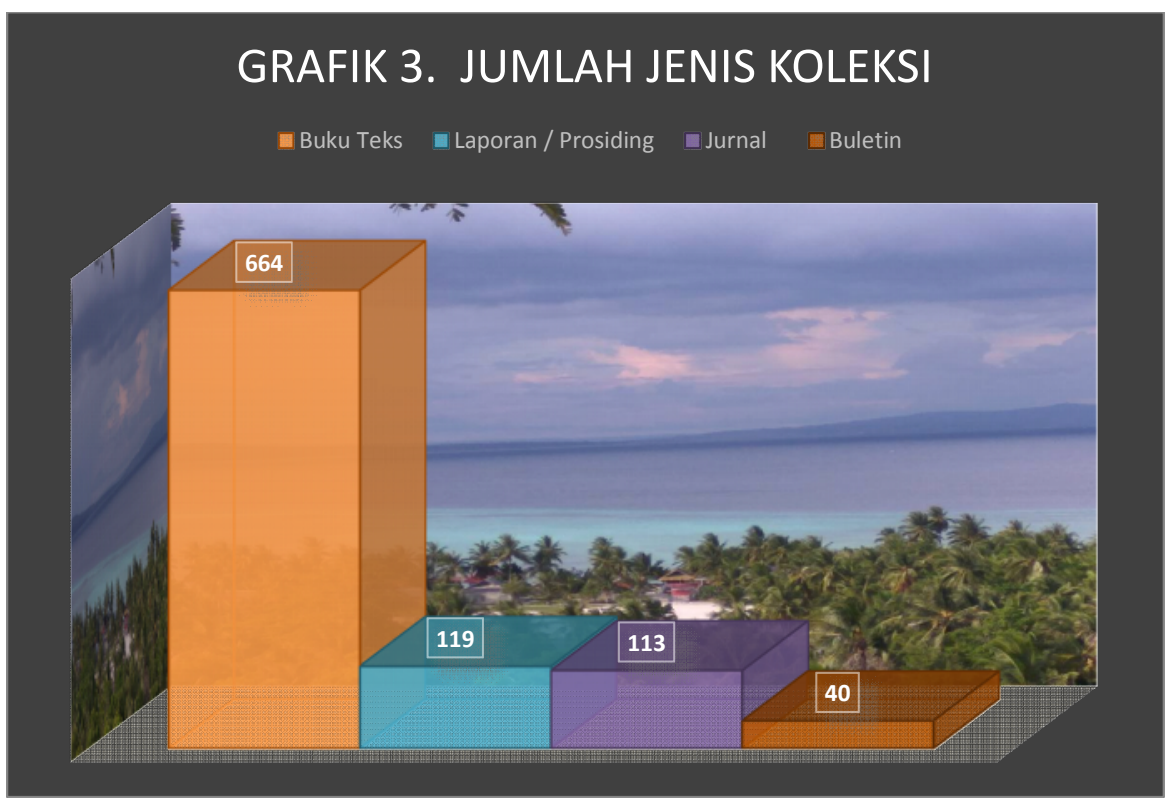

Gambar 3. Grafik Jumlah Jenis Koleksi Perpustakaan BBRSEKP Tahun 2016

\section{PERCENTAGE OF COLLECTIONS}

Secara garis besar, koleksi yang ada di Perpustakaan BBRSEKP di bagi menjadi empat jenis besar, yaitu : Buku Teks, Laporan /Prosiding, Jurnal dan Bultein.
Untuk melihat nilai persentase dari keseluruhan koleksi berdasarkan jenis koleksi dijelaskan dengan grafik berikut : 


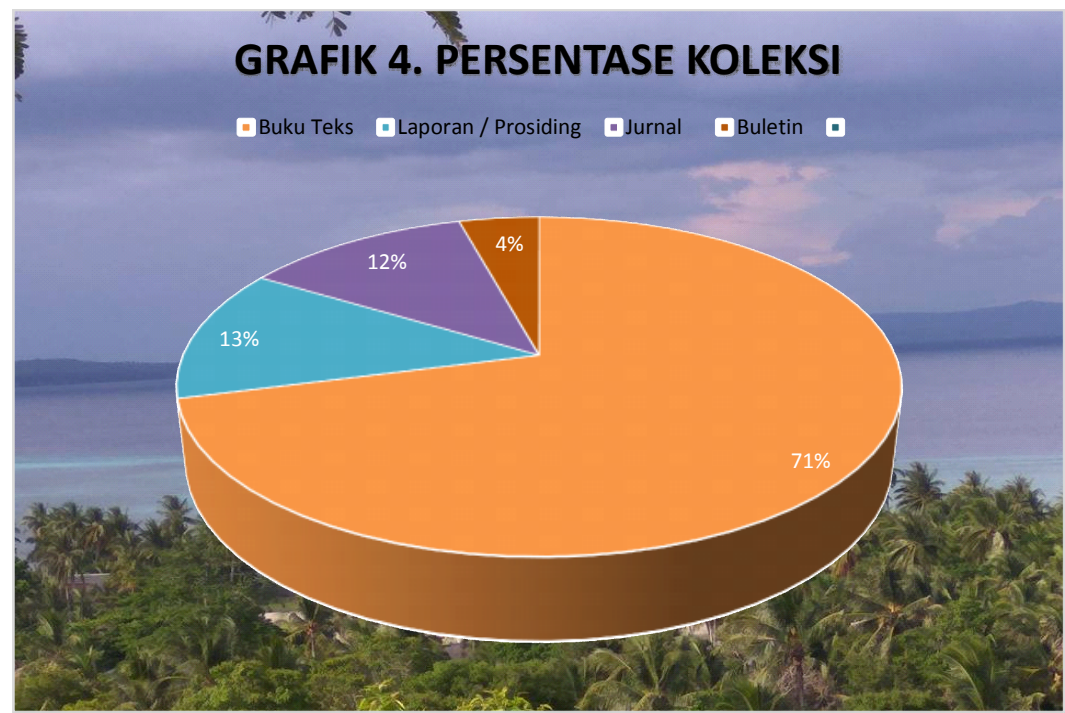

Gambar 4. Grafik persentase keseluruhan koleksi perpustakaan BBRSEKP tahun 2016

\section{COLLECTION AND POPULATION RATIO (CPR) $=10.5$}

Dari data diatas, maka dapat diketahui rasio koleksi terhadap populasi adalah :

$$
\begin{aligned}
& C P R=\frac{T C}{T P} \\
& C P R=\frac{936}{89} \\
& C P R=10.5
\end{aligned}
$$

Dimana :

- Collection and Population Ratio (CPR) adalah rasio antara koleksi bahan pustaka yang dimiliki oleh perpustakaan BBRSE-KP dengan total populasi sivitas akademika BBRSE-KP.

- Total Collection (TC) adalah total koleksi yang dimiliki oleh perpustakaan BBRSE-KP secara keseluruhan.

- Total Population (TP) adalah total seluruh populasi sivitas akademika BBRSE-KP

Jadi setiap 1 orang dalam sivitas akademika BBRSE-KP disediakan 11 eksemplar buku dari berbagai subjek.

\section{KEMUTAKHIRAN KOLEKSI}

Kemutakhiran koleksi berdasarkan tahun terbit buku yang ada di koleksi perpustakaan BBRSE-KP dijelaskan dalam data berikut :

Tabel 3. Total koleksi berdasarkan tahun terbit

\begin{tabular}{|c|cc|} 
No. & Tahun & Jumlah \\
\hline 1 & $\leq 2005$ & 205 \\
3 & $2006-2010$ & 571 \\
& $2011-2015$ & 160 \\
& Total & $\mathbf{9 3 6}$ \\
\hline
\end{tabular}

Dan dalam persentase, dapat di lihat pada Grafik 5 berikut ini,
Jadi, buku koleksi perpustakaan BBPSE-KP yang terbit tahun $2011-2015$ hanya $17 \%$ dari total koleksi. 


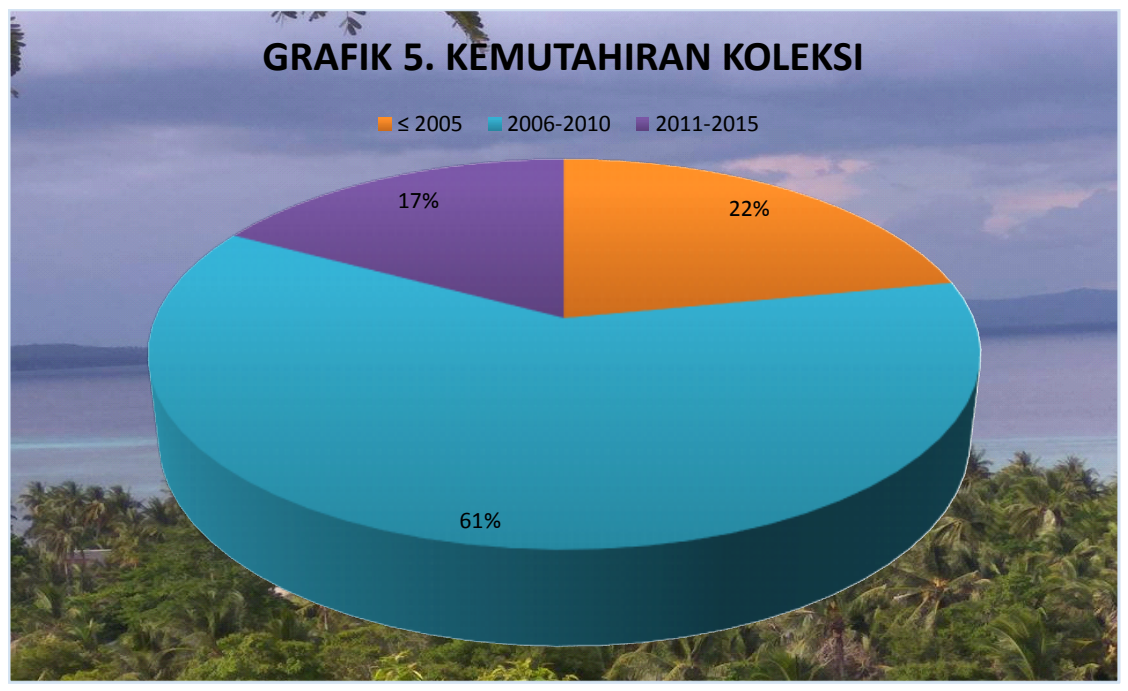

Gambar 5. Grafik pertambahan jenis koleksi di Perpustakaan BBRSEKP Tahun 2016

\section{PENGADAAN KOLEKSI}

Pengadaaan koleksi tahun terakhir atau tahun 2016 tidak ada untuk pembelian, akan tetapi ada buku, jurnal dan prosiding yang diberikan secara hibah dari institusi di luar BBRSEKP

\section{JAM PELAYANAN $=40 \mathrm{Jam} /$ pekan}

Jam buka pelayanan perpustakaan selama 2016 adalah 40 jam perpekan. Dan hingga saat ini belum ada tambahan jam pelayanan perpustakaan.

\section{8. $\mathrm{OPAC}=1$ Personal Computer}

Jumlah terminal computer yang digunakan untuk OPAC (Online Public Access Catalogue ) hanya ada satu dengan kondisi yang sangat memperihatinkan.

\section{LIBRARIAN RATIO $=1: 3$}

Rasio pustakawan terhadap total pegawai staf perpustakaan adalah sebagai berikut:

$$
\begin{aligned}
& L i b R=\frac{T L i b}{T S L i b} \\
& L i b R=\frac{2}{1} \\
& L i b R=2
\end{aligned}
$$

Dimana :

- $\quad$ Librarian Ratio (LibR) adalah Rasio antara jumlah pustakawan dan total Staf Perpustakaan BBPSE-KP

Total Librarian (TLib) adalah total pustakawan yang bekerja aktif di BBPSE-KP s.d Desember 2016

Total Staf Library (TSLib) adalah total staf yang aktif bekerja di BBPSE-KP

Dari hasil diatas, dapat diartikan bahwa rasio pustakawan terhadap staf perpustakaan adalah $2: 1$

\section{LIBRARY REGISTRATION= 89}

Sistem keanggotaan di perpustakaan BBRSE-KP bersifat menyeluruh, artinya seluruh sivitas akademika BBPSE-KP sudah langsung menjadi anggota perpustakaan BBRSE-KP, dan untuk melakukan peminjaman, dilakukan aktivasi dengan langsung mendatangi ruang perpustakaan untuk verifikasi data. Dan hingga bulan Desember 2016 tercatat 89 anggota aktif dengan rincian sebagai berikut : 
Tabel 5. Anggota Aktif di Perpustakaan BBRSEKP per Tahun 2016
No.
Bagian
Jumlah

\begin{tabular}{|l|lc|}
\hline 1 & PNS & 67 \\
2 & Tenaga Kontrak & 22 \\
& & 89
\end{tabular}

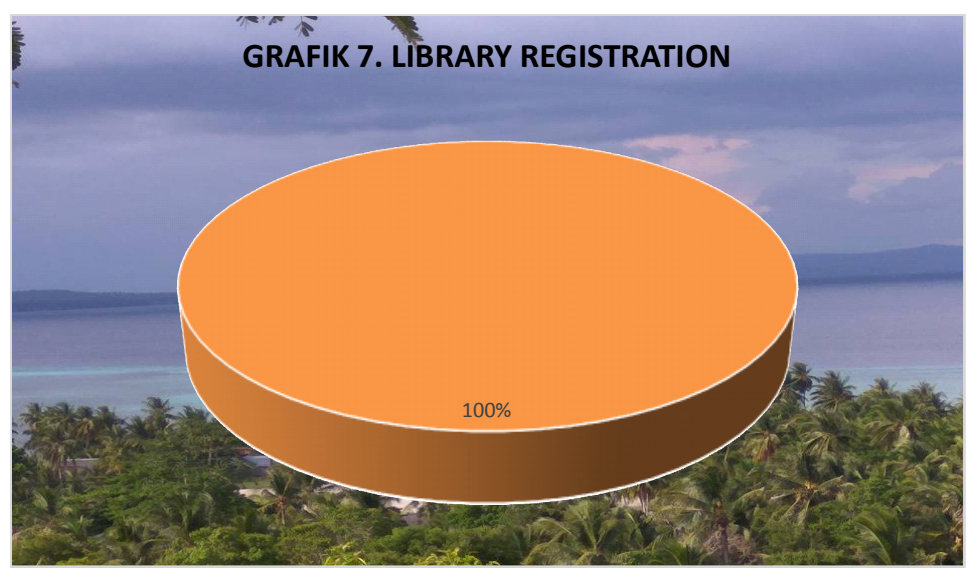

Gambar 6. Grafik Keanggotaan di perpustakaan BBRSEKP Tahun 2016

Dalam persentase, dapat dilihat menggunakan rumus :

$$
\begin{aligned}
& R P P=\frac{L R}{J P} X 100 \% \\
& R P P=\frac{89}{89} X 100 \% \\
& R P P=100 \%
\end{aligned}
$$

Dimana :

Library Registration (LR) adalah jumlah anggota yang terdaftar sebagai pemakai aktif di perpustakaan.

Jurisdiction of Population (JP) adalah jumlah populasi perguruan tinggi yang wajib dilayani oleh perpustakaan, dalam hal ini adalah jumlah sivitas akademika BBPSE-KP

- Registration as a Percentage of Population (RPP) adalah persentase angota yang terdaftar sebagai pengguna aktif perpustakaan terhadap populasi balai yang wajib dilayani.

Hal ini berarti, sudah $100 \%$ pemustaka yang telah mengaktifkan keanggotaan perpustakaan sampai dengan desember 2016.

\section{KESIMPULAN DAN SARAN}

Melihat paparan diatas dapat di simpulkan bahwa isi laporan yang dibuat sudah cukup baik dan dapat dipahami oleh pemustaka dan stakeholder, dalam hal ini pihak pimpinan di BBRSEKP, baik dari segi undersandability maupun dari readability. Kelebihan laporan tahunan yang dibuat secara lengkap dan didesain secara menarik dengan tambahan bentuk grafik dan tabel, akan menjadi sebuah dokumen yang sangat efektif untuk menginformasikan sekaligus mempromosikan perpustakaan BBRSEKP. Jumlah pengguna potensial sebesar 89 orang, total koleksi yang di miliki sejumlah 936 eksemplar. Penambahan koleksi secara pembelian yang tidak ada pada tahun 2016 tetap menjadikan besaran persentase buku berdasarkan jenis buku teks sebesar $71 \%$. Rasio pengguna sebanyak 10.5 atau di bulatkan menjadi 11 , yang berarti setiap pemustaka di lingkup BBRSEKP mempunyai kesempatan untuk meminjam sampai dengan 11 eks. Buku, namun kemutakhiran koleksi hanya sebesar $17 \%$. Jumlah jam pelayanan selama 40 jam per pekan. Dukungan sarana katalog daring hanya 1 buah komputer. Rasio pustakawan terhadap staf perpustakaan adalah 2:1 dengan library registration sebesar $100 \%$.

\section{DAFTAR PUSTAKA}

Arikunto, Suharsimi. 2015. Prosedur Penelitian Suatu Pendekatan Praktik. PT Rineka Cipta, Jakarta.

Bungin, Burhan, 2012. Metode Penelitian Kualitatif: Aktualisasi Metodologis kearah ragam varian kontemporer, Rajawali pers Ed. 1 cet. 9, Jakarta. 
Courtis,John K, 1998. Readibility of Annual Reports : Western vs Asian Evidence. Accounting, Auditing \& Accountability Journal. Vol.8 No. 2 pp. 4-17

FASB, 1974 . Statemant of Financial Acoounting Standards No.2. Acoounting for Research and Development Cost.

Saleh, Abdul Rahman, 2013. Indikator Kinerja Perpustakaan Menurut ISO 11620: 2008 (Information and Documentation - Library Performance Indicators) (PDF Download Available). Available from: https://www.researchgate.net/publication/ 303805059 Indikator Kineria Perpustakaan Menurut I SO 116202008 Information and Documentation - Library Performance Indicators [accessed Sep 19, 2017].

Irawan, 2006. Penelitian Kualitatif Dalam Penerapan, Terj. Depdiknas Pusat Bahasa, Balai Bahasa Pekanbaru, 2000

ISO 11620:2008 Information and documentation - $\mathrm{Li}$ brary performance indicators " tersedia pada https://www.iso.org/standard/37853.html, (diakses pada 14 September 2017)

ISO 11620:2008 Information and documentation - Library performance indicators " tersedia pada https://www.iso.org/standard/56755.html , (diakses pada 14 September 2017)
Lamatenggo,Nina. 2012. Teori Kinerja dan Pengkurannya. PT Bumi Aksara., Jakarta

Pusat Bahasa,2008. Kamus Besar Bahasa Indoensia ed.Keempat, Departemen Pendidikan Nasional, Jakarta

Pendit, Putu Laxman, 2009. Perpustakaan Digital : Kesinabungan dan dinamika; Cita Karyakarsa Mandiri, Jakarta

Rahayuningsih, F. 2007, Pengelolaan Perpustakaan, Graha llmu, Yogyakarta:

Setyorini, Dyah, 2007. Laporan Tahunan VS Ringkasan Laporan Tahunan. Jurnal Ekonomi dan Pendidikan, Volume 4 Nomor 1.

Sugiyono, 2013 Metode Penelitian Kuantitatif, Kualitatif, dan R\&D.Cetakan ke-19. Bandung: Alfabeta.

Sutarno,N.S. 2006. Perpustakaan dan Masyarakat Ed. Rev. Jakarta : Sagung Seto

Wibowo, 2007. Manajemen Kinerja. Jakarta: Raja Grafindo Persada.

Yamamoto, Gonca Telli, 2007. Understanding Costumer Value Concept: Key To Success, Maltepe University, Fakulty of Economics and Administrative science. Business Department, 
J.Pari Vol. 4 No. 1 Juli 2018 : 